\title{
UPTAKE OF INORGANIC NITROGEN AND SEAWEED SURFACE AREA:VOLUME RATIOS
}

\section{G. ROSENBERG}

Division of Biological Sciences, University of Michigan, Ann Arbor, MI 48109 (U.S.A.)

J. RAMUS

Duke University Marine Laboratory, Beaufort, NC 28516 (U.S.A.)

(Accepted for publication 7 February 1984)

\begin{abstract}
Rosenberg, G. and Ramus, J., 1984. Uptake of inorganic nitrogen and seaweed surface area :volume ratios. Aquat. Bot., 19:65-72.

Surge uptake of ammonium and nitrate by four intertidal seaweed species was examined under standard conditions $\left(16.5\right.$ or $\left.20^{\circ} \mathrm{C}, 72 \mu \mathrm{E} \mathrm{m}^{-2} \mathrm{~s}^{-1}\right)$, at both subsaturating and saturating initial nutrient concentrations. Uptake rates were positively correlated with the surface area:volume (SA:V) ratio of the thallus: Ulva curvata (Kützing) DeToni $>$ Fucus evanescens $\mathrm{C}$. Agardh $\approx$ Gracilaria tikuahiae McLachlan > Codium decorticatum (Woodward) Howe. A positive correlation was also found for the relationship between $\mathrm{SA}: \mathrm{V}$ and the initial slope of the curves of uptake rate vs. external concentration. These results support the predictions of an earlier functional-form model, and suggest the usefulness of the $\mathrm{SA}: \mathrm{V}$ ratio as a comparative index of nutrient uptake capability in co-occurring seaweeds.
\end{abstract}

\section{INTRODUCTION}

The recent identification of functional-form groups among seaweeds (Littler and Littler, 1980; Littler et al., 1983) has led to the emergence of testable general hypotheses about seaweed survival strategies. Based on a number of morphological, physiological and ecological attributes, Littler and Littler (1980, their Tables 1 and 2) distinguished between opportunistic and persistent strategies, representing the extremes along a continuum of possible strategies. Opportunistic forms were characterized by relatively simple (undifferentiated) thalli with a high surface area:volume $(\mathrm{SA}: \mathrm{V})$ ratio. Persistent forms, on the other hand, were differentiated both structurally and functionally and had a low SA:V ratio. The functionalform concept can be related to the survival strategies proposed by Grime (1979) for terrestrial plants. Accordingly, opportunistic species would correspond to terrestrial ruderals (R-strategists), whereas persistent species would include both competitive and stress-tolerant forms (C- and S-strategists, respectively, sensu Grime, 1979). 
In view of concomitant physiological and ecological trade-offs, Littler and Littler (1980) predicted that opportunistic seaweeds should show both high net primary productivity and high rates of nutrient uptake, providing a potential for rapid growth. In contrast, persistent forms, by virtue of their investment in non-photosynthetic structural tissue, should show lower net productivity and nutrient uptake rates and, thus, slower growth. Several studies (e.g. Kanwisher, 1966; Littler, 1980) have borne out these predictions for the relationship between morphological form and photosynthetic capacity. To date, however, little comparative information is available on the relationship between morphological form and nutrient uptake rates. This study was undertaken in order to test this prediction of the Littler and Littler functional-form model for some seaweeds from the Atlantic coast of North America.

\section{MATERIALS AND METHODS}

The green seaweeds Codium decorticatum (Woodward) Howe and Ulva curvata (Kützing) DeToni and the red seaweed Gracilaria tikvahiae McLachlan (formerly identified as G. foliifera (Forsskål) Børgesen) were collected in December-January and April-June (1980) from the intertidal zone near Beaufort, North Carolina $\left(34^{\circ} 43^{\prime} \mathrm{N}, 76^{\circ} 40^{\prime} \mathrm{W}\right)$. These waters are characterized by year-round low levels of available inorganic nitrogen $\left(\mathrm{NO}_{3}^{-}+\right.$ $\mathrm{NO}_{2}^{-}+\mathrm{NH}_{4}^{+}$, annual mean $=0.82 \mu$ g-at. $\mathrm{N} \mathrm{l}^{-1}$; Thayer, 1974). The brown seaweed Fucus evanescens C. Agardh (formerly $F$. distichus Linnaeus subsp. edentatus (de la Pylaie) Powell) was collected in April (1982) from the intertidal zone of Cranberry Cove, on the Atlantic coast of Nova Scotia $\left(44^{\circ} 30^{\prime} \mathrm{N}, 63^{\circ} 55^{\prime} \mathrm{W}\right)$. By this time, ambient inorganic $\mathrm{N}$ levels at this site had fallen from a seasonal winter maximum of $>6.0 \mu \mathrm{g}$-at. $\mathrm{N}^{-1}$ to low spring-summer levels of $<1.0 \mu$ g-at. $\mathrm{N}^{-1}$ (Probyn, 1982). Although the growth of algae at both sites may be seasonally limited by $\mathrm{N}$ availability (Thayer, 1974; Probyn, 1982), the identity of the growth-limiting resources at the time of the experiments was not determined.

The seaweeds were returned to the laboratory where apical vegetative portions of the thalli were cut with a razor blade to yield plants weighing ca. $150 \mathrm{mg}$ dry weight for $U$. curvata, $250 \mathrm{mg}$ for G. tikvahiae, $990 \mathrm{mg}$ for $C$. decorticatum and $330 \mathrm{mg}$ for $F$. evanescens. These plants were gently wiped with a Kimwipe and held in a flow-through seawater system (ambient seawater for Beaufort plants, low-N seawater collected the previous summer for $F$. evanescens). U. curvata, $G$. tikvahiae and $C$. decorticatum were used for uptake measurements the following day, whereas $F$. evanescens was held for several days (under $105 \mu \mathrm{E} \mathrm{m}^{-2} \mathrm{~s}^{-1}$ ) in order to deplete its internal nitrogen reserves.

During uptake measurements, the plants were sandwiched between two pieces of $9.0 \times 11.5 \mathrm{~cm}$ wide-mesh $(7 \mathrm{~mm})$ plastic screening. This was done to prevent self-overlap and to hold the plants in an attached posi- 
tion. The plants were suspended in glass beakers containing 11 of filtered (Gelman GF/C, $1.2 \mu \mathrm{m}$ pore size) seawater which had been spiked up to the desired initial concentration with an aliquot from a concentrated stock solution of $\mathrm{NH}_{4} \mathrm{Cl}$ or $\mathrm{NaNO}_{3}$. The concentration of dissolved inorganic $\mathrm{N}$ in the unspiked seawater was negligible $\left(<0.1 \mu \mathrm{g}\right.$-at. $\left.\mathrm{N}^{-1}\right)$. Mixing was provided by magnetic stir bars in each beaker.

All incubations were carried out between 10.00 and $16.00 \mathrm{~h}$ at $16.5^{\circ} \mathrm{C}$ ( $F$. evanescens) or $20^{\circ} \mathrm{C}$ (all other species) under $72 \mu \mathrm{E} \mathrm{m}^{-2} \mathrm{~s}^{-1}$ provided by "cool-white" fluorescent tubes (Sylvania F48T12-CW-VHO). This irradiance was above the photosynthetic light compensation point, but below saturation for all four species. It is not known whether inorganic $\mathrm{N}$ uptake was saturated at this irradiance, although Hanisak and Harlin (1978) reported that uptake by Codium fragile ssp. tomentosoides (van Goor) Silva saturated at $7-28 \mu \mathrm{E} \mathrm{m}^{-2} \mathrm{~s}^{-1}$, depending on the $\mathrm{N}$ source.

Uptake was monitored as the disappearance of ammonium or nitrate. Ammonium was determined using the phenol hypochlorite method (Solorzano, 1969), while nitrate and nitrite were analyzed according to the methods of Strickland and Parsons (1972). Incubation times were 20 or 30 min. Each uptake-rate measurement was carried out at least three, and usually six, times. No change in inorganic $\mathrm{N}$ concentration was observed in the absence of thalli.

Surface area:volume $(\mathrm{SA}: \mathrm{V})$ ratios were determined on at least five individuals of each species. Volumes were measured from the volume of seawater displaced in a graduated cylinder. Surface areas were determined by planimetry of traced outlines of the blotted seaweeds. Segments of C. decorticatum were assumed to approximate a cylinder. Seaweed dry weights were determined after desiccation for $24 \mathrm{~h}$ at $90^{\circ} \mathrm{C}$.

\section{RESULTS AND DISCUSSION}

Among the four species of seaweeds studied, Ulva curvata had the simplest thallus structure (sheetlike cellular bilayer composed entirely of photosynthetic tissue) and the highest $\mathrm{SA}: \mathrm{V}$ ratio $\left(165 \pm 16 \mathrm{~cm}^{2}: \mathrm{cm}^{3} ; \bar{x} \pm 95 \%\right.$ C.I.). Next in order of increasing morphological complexity and decreasing SA:V were Fucus evanescens (photosynthetic surface layer, underlain by non-photosynthetic cortex and medulla, $\mathrm{SA}: \mathrm{V}=29.5 \pm 1.6 \mathrm{~cm}^{2}: \mathrm{cm}^{3}$ ) and Gracilaria tikvahiae (photosynthetic cortex surrounding a colourless parenchymatous medulla, $\mathrm{SA}: \mathrm{V}=27.9 \pm 3.5 \mathrm{~cm}^{2}: \mathrm{cm}^{3}$ ). The difference in SA:V ratios between $F$. evanescens and $G$. tikvahiae was not statistically significant (Student's $t$-test, $P>0.05$ ). The species with the lowest SA:V ratio $\left(8.9 \pm 0.3 \mathrm{~cm}^{2}: \mathrm{cm}^{3}\right)$ was Codium decorticatum. The thallus of this species is coenocytic, comprising a surface layer of photosynthetic utricles surrounding a colourless medullary region. Both the photosynthetic capacity (Rosenberg and Ramus, 1982) and the light-saturated growth rates (Ramus and Rosenberg, 1980) of three of these species have been shown to be 
correlated with the SA:V ratios: $U$. curvata $>G$. tikvahiae $>C$. decorticatum.

The inorganic $\mathrm{N}$ uptake rates measured in this study represent transient responses to nutrient pulses ("surge uptake" sensu Conway et al., 1976). As such, they should be distinguished from acclimated (steady state) uptake rates measured in continuous culture (Probyn and Chapman, 1982).

Ammonium uptake rates at an initial concentration of $10 \mu \mathrm{M}\left(\mathrm{V}_{10}^{\mathrm{NH}_{4}^{+}}\right)$are shown in Fig. 1. This initial concentration is below saturation for all four species, and represents the highest concentration to which these seaweeds are likely to be exposed in the natural environment, either seasonally (in Nova Scotia) or during storms (in either area). Uptake rate was correlated with the SA:V ratio (Fig. $1 ; r^{2}=0.984, P<0.01$ ). A similar relationship between ammonium uptake rate and $\mathrm{SA}: \mathrm{V}$ ratio was observed at an initial concentration of $40 \mu \mathrm{M}\left(\mathrm{V}_{40}^{\mathrm{NH}_{4}^{+}}\right.$, Fig. $\left.2 ; r^{2}=0.963, P<0.05\right)$. This initial concentration was above saturation for $C$. decorticatum (Rosenberg and Paerl, 1981) and $G$. tikvahiae (Rosenberg, 1981), barely saturating for $U$. curvata, and below saturation for $F$. evanescens (unpublished data). At saturation, the maximum realizable uptake rate per unit of biomass would be expected to depend on the number of ion pump active sites and, thus, to a first approximation, on the $\mathrm{SA}: \mathrm{V}$ ratio of the thallus.

Nitrate uptake rates were measured for $U$. curvata (high SA:V) and G. tikvahiae (lower SA:V). At an initial concentration of $10 \mu \mathrm{M}$ nitrate, the uptake rate of $U$. curvata exceeded that for $G$. tikvahiae (Table I).

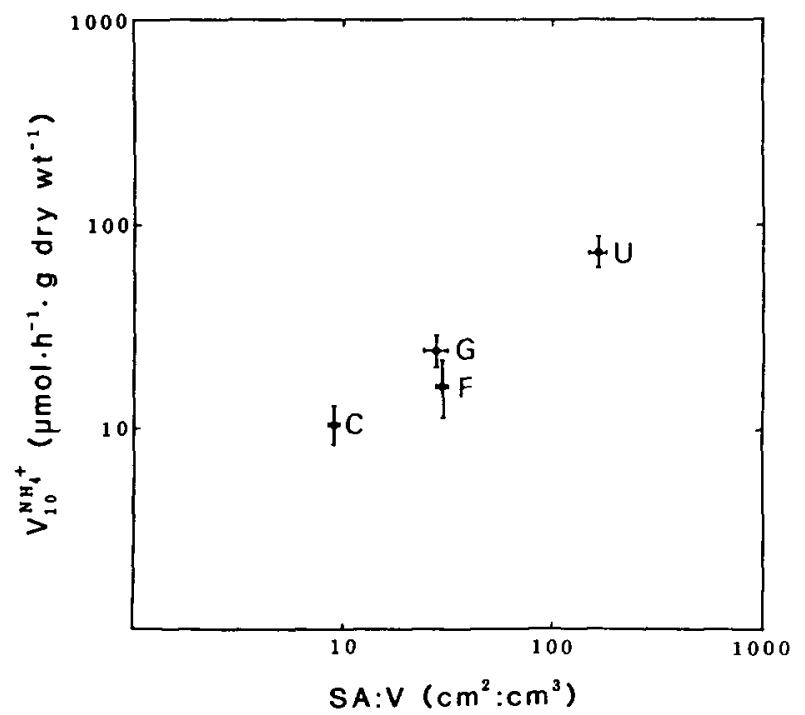

Fig. 1. Surge uptake of ammonium at an initial concentration of $10 \mu \mathrm{M}\left(\mathrm{V}_{10}^{\mathrm{NH}_{4}^{+}}\right)$as a function of seaweed $\mathrm{SA}: \mathrm{V}$ ratios. $\mathrm{C}=$ Codium decorticatum; $\mathrm{G}=$ Gracilaria tikvahiae; $\mathrm{F}=$ Fucus evanescens; $\mathrm{U}=$ Ulva curvata. Mean values $\pm 95 \%$ C.I. 
A similar relationship was observed at $30 \mu \mathrm{M}$ nitrate (Table I), which was above saturation for both species. For both $U$. curvata and $G$. tikvahiae, uptake rates of ammonium at $10 \mu \mathrm{M}$ were higher than for nitrate at the same initial concentration. This probably reflects the increased energetic cost of reducing nitrate to ammonium within the cell via nitrate reductase (Syrett, 1981).

Healey (1980) has argued that the initial slope of the curve of uptake rate versus external nutrient concentration is the best index for comparing the uptake efficiency of a species at low ambient nutrient concentrations. Based on uptake rates for three species at initial ammonium concentrations $\leqslant 5 \mu \mathrm{M}$ (Rosenberg, 1981; Rosenberg and Paerl, 1981), the calculated initial slopes were $9.2 \mu \mathrm{mol} \mathrm{NH} \mathrm{NH}_{4}^{+} \mathrm{h}^{-1} \mathrm{~g}$ dry wt. ${ }^{-1}\left[\mu \mathrm{mol} \mathrm{NH} \mathrm{NH}_{4}^{+1}\right]^{-1}$ for $U$. curvata, 2.2 for $G$. tikvahiae and 0.8 for $C$. decorticatum. The ratio of these initial slopes, 11.9: 2.8: 1, was similar to the ratios of the SA:V

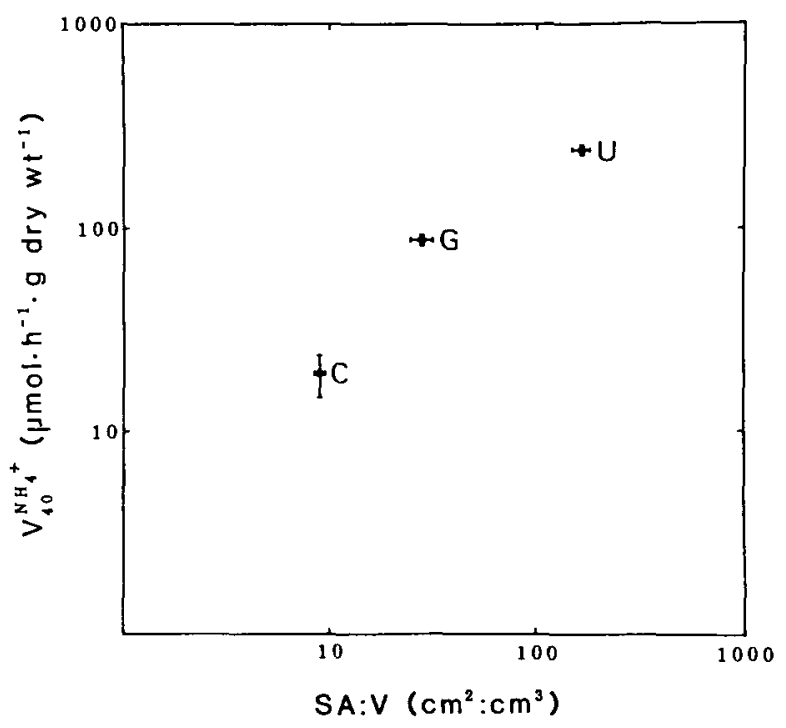

Fig. 2. Surge uptake of ammonium at an initial concentration of $40 \mu \mathrm{M}\left(\mathrm{V}_{40}^{\mathrm{NH}_{4}^{+}}\right)$as a function of seaweed SA:V ratios. Mean values $\pm 95 \%$ C.I.

\section{TABLE I}

Surge uptake of nitrate ( $\mu \mathrm{mol} \mathrm{NO}_{3}^{-} \mathrm{h}^{-1} \mathrm{~g} \mathrm{dry} \mathrm{wt.}{ }^{-1}$ ) at initial concentrations of $10 \mu \mathrm{M}$ $\left(\mathrm{V}_{10}^{\mathrm{NO}_{3}^{-}}\right)$and $30 \mu \mathrm{M}\left(\mathrm{V}_{30}^{\mathrm{NO}_{3}^{-}}\right)$for Ulva curvata and Gracilaria tikvahiae. Mean values \pm $95 \%$ C.I.

\begin{tabular}{lcrr}
\hline Species & $\mathrm{SA}: \mathrm{V}$ & \multicolumn{1}{c}{$\mathrm{V}_{10}^{\mathrm{NO}_{3}^{-}}$} & \multicolumn{2}{c}{$\mathrm{V}_{30}^{\mathrm{NO}_{3}^{-}}$} \\
\hline U. curvata & \multicolumn{1}{c}{165} & $43.2 \pm 3.7$ & $65.4 \pm 10.9$ \\
G. tikvahiae & 27.9 & $3.1 \pm 1.0$ & $8.2 \pm 4.2$ \\
\hline
\end{tabular}


values, 18.5: 3.1 : $1\left(r^{2}=0.998, P<0.05\right)$. Similarly, for nitrate uptake, the initial slopes were $7.0 \mu \mathrm{mol} \mathrm{NO} \mathrm{NO}_{3}^{-} \mathrm{h}^{-1} \mathrm{~g}$ dry wt. ${ }^{-1}\left[\mu \mathrm{mol} \mathrm{NO} \mathrm{NO}^{-} l^{-1}\right]^{-1}$ for $U$. curvata and 0.4 for G. tikvahiae.

Overall, the results support the predictions of the functional-form model of Littler and Littler (1980). The SA:V ratio was positively correlated with uptake rates of ammonium and nitrate and with the initial slope of the uptake curves. Similar results have been reported for phosphate uptake by several species of phytoplankton (Smith and Kalff, 1982). The only comparable data for seaweeds are those of Odum et al. (1958). They monitored uptake as the disappearance of ${ }^{32} \mathrm{P}$-phosphate from seawater in bottles containing the seaweeds. Although actual phosphate uptake rates and the external concentration required to saturate uptake were not determined, the rate of disappearance of radioactivity was found to be correlated with the calculated SA:V ratios of the thalli.

Thus, lower uptake rates seem to be associated with lower SA:V ratios and increasing structural complexity. This suggests that the development of structural complexity in persistent forms, while conferring advantages such as resistance to desiccation (Dromgoole, 1980), grazing (Littler et al., 1983) and wave action (Littler and Littler, 1980), comes at the cost of metabolically-active surface area. The importance of factors other than uptake rate is reflected in the fact that, even in nutrient-poor environments, many numerically abundant seaweed species do not have high SA:V ratios.

The usefulness of the SA:V ratio to predict the nutrient uptake efficiency of a species depends on a number of factors, including the nutrient status of the thallus, the substrate affinity of the nutrient ion pumps, the proportion of metabolically-active to total surface area, and the surrounding water motion (Gavis, 1976). For example, the tightly clumped turf morphology of certain filamentous seaweeds may result in decreased nutrient uptake rates in spite of their high SA:V ratio. This could arise due to decreased water motion and overlapping diffusion gradients within the turf unit (Littler and Arnold, 1980). The kinetics of phytoplankton nutrient uptake have been shown to differ both between similar-sized clones of a single species (Hecky and Kilham, 1974) and within a single clone, as a function of the cellular N quota (Eppley and Renger, 1974). Nevertheless, for seaweed species co-occurring in a particular habitat, the SA:V ratio appears to be a useful comparative index of nutrient uptake capability.

\section{ACKNOWLEDGEMENTS}

This research was supported by National Science Foundation grants OCE 77-27130 (to G.R.) and OCE 78-18698 (to J.R.) from the Biological Oceanography Program. During part of this research, G.R. was supported by a Killam Post-doctoral Fellowship from Dalhousie University. We thank Drs. P. and S. Kilham and Dr. J. Lehman for providing helpful comments on the manuscript. 


\section{REFERENCES}

Conway, H.L., Harrison, P.J. and Davis, C.O., 1976. Marine diatoms grown in chemostats under silicate and ammonium limitation. II. Transient response of Skeletonema costatum to a single addition of the limiting nutrient. Mar. Biol., 35: 187-199.

Dromgoole, F.I., 1980. Desiccation resistance of intertidal and subtidal algae. Bot. Mar., 23: 149-159.

Eppley, R.W. and Renger, E.H., 1974. Nitrogen assimilation of an oceanic diatom in nitrogen-limited continuous culture. J. Phycol., 10: 15-23.

Gavis, J., 1976. Munk and Riley revisited: nutrient diffusion transport and rates of phytoplankton growth. J. Mar. Res., 34: 161-179.

Grime, J.P., 1979. Plant Strategies and Vegetation Processes. Wiley, Chichester, $222 \mathrm{pp}$.

Hanisak, M.D. and Harlin, M.M., 1978. Uptake of inorganic nitrogen by Codium fragile subsp. tomentosoides (Chlorophyta). J. Phycol., 14: 450-454.

Healey, F.P., 1980. Slope of the Monod equation as an indicator of advantage in nutrient competition. Microbiol. Ecol., 5: 281-286.

Hecky, R.E. and Kilham, P., 1974. Environmental control of phytoplankton cell size. Limnol. Oceanogr., 19: 361-366.

Kanwisher, J.W., 1966. Photosynthesis and respiration in some seaweeds. In: H. Barnes (Editor), Some Contemporary Studies in Marine Science. Allen and Unwin, London, pp. $407-420$.

Littler, M.M., 1980. Morphological form and photosynthetic performances of marine macroalgae: tests of a functional/form hypothesis. Bot. Mar., 22: 161-165.

Littler, M.M. and Arnold, K.E., 1980. Sources of variability in macroalgal primary productivity: sampling and interpretative problems. Aquat. Bot., 8: 141-156.

Littler, M.M. and Littler, D.S., 1980. The evolution of thallus form and survival strategies in benthic marine macroalgae: field and laboratory tests of a functional-form mode.. Am. Nat., 116: 25-44.

Littler, M.M., Littler, D.S. and Taylor, P.R., 1983. Evolutionary strategies in a tropical barrier reef system: functional-form groups of marine macroalgae. J. Phycol., 19: 229-237.

Odum, E.P., Kuenzler, E.J. and Blunt, M.X., 1958. Uptake of ${ }^{32} \mathrm{P}$ and primary productivity in marine benthic algae. Limnol. Oceanogr., 3: 340-345.

Probyn, T.A., 1982. Summer growth of Chordaria flagelliformis (Phaeophyta): physiological strategies in a nitrogen-stressed environment. Ph.D. Thesis, Dalhousie University, Halifax, Nova Scotia, $161 \mathrm{pp}$.

Probyn, T. and Chapman, A.R.O., 1982. Nitrogen uptake characteristics of Chordaria flagelliformis (Phaeophyta) in batch mode and continuous mode experiments. Mar. Biol., $71:$ 129-133.

Ramus, J. and Rosenberg, G., 1980. Diurnal photosynthetic performance of seaweeds measured under natural conditions. Mar. Biol., 56: 21-28.

Rosenberg, G., 1981. Ecological growth strategies in the seaweeds Gracilaria foliifera (Rhodophyceae) and Ulva sp. (Chlorophyceae). Ph.D. Thesis, Yale University, New Haven, Connecticut, 151 pp.

Rosenberg, G. and Paerl, H.W., 1981. Nitrogen fixation by blue-green algae associated with the siphonous green seaweed Codium decorticatum: effects on ammonium uptake. Mar. Biol., 61: 151-158.

Rosenberg, G. and Ramus, J., 1982. Ecological growth strategies in the seaweeds Gracilaria foliifera (Rhodophyceae) and Ulva sp. (Chlorophyceae): photosynthesis and antenna composition. Mar. Ecol. Prog. Ser., 8: 233-241.

Smith, R.E.H. and Kalff, J., 1982. Size-dependent phosphorus uptake kinetics and cell quota in phytoplankton. J. Phycol., 18:275-284.

Solórzano, L., 1969. The determination of ammonia in natural waters by the phenol hypochlorite method. Limnol. Oceanogr., 14: 799-801. 
Strickland, J.D.H. and Parsons, T.R., 1972. A Practical Handbook of Seawater Analysis. 2nd edn., Fisheries Research Board of Canada, Ottawa, 310 pp.

Syrett, P.J., 1981. Nitrogen metabolism of microalgae. In: T. Platt (Editor), Physiological Bases of Phytoplankton Ecology. Can. Bull. Fish. Aquat. Sci., 210: 182-210.

Thayer, G.W., 1974. Identity and regulation of nutrients limiting phytoplankton production in the shallow estuaries near Beaufort, North Carolina. Oecologia (Berl.), 14: $75-92$. 